\title{
Research on Higher Education Quality Assurance in China During the Popularization
}

\author{
Jing Ma \\ Clinical College, Guilin Medical University, Guilin, China \\ Email address: \\ majing_carol@163.com \\ To cite this article: \\ Jing Ma. Research on Higher Education Quality Assurance in China During the Popularization. Higher Education Research. \\ Vol. 5, No. 1, 2019, pp. 1-4. doi: 10.11648/j.her.20200501.11
}

Received: December 9, 2019; Accepted: December 21, 2019; Published: January 6, 2020

\begin{abstract}
Higher education has entered the stage of popularization in China. At the end of the 20th century, the Chinese government made a major decision to accelerate the development of higher education. To the 21 st century, the scale of higher education has expanded unprecedentedly. The rapid increase in Numbers has caused many quality problems. It has attracted more and more attention of scholars and society how to develop higher education with high quality. In view of the problem, this paper provides an overview of higher education quality assurance in the world, including its rise, development and new trend. To adapt to higher education globalization, we should further deepen reform and innovation, and accelerate the construction and improvement of quality assurance to effectively improve high education quality. Of course, we also do it from the advanced experience of developed countries and reality in China. So we will take measures to improve higher education quality in China in future. We can also call it prospect for higher education quality. For example, there will be special policy and legal basis for quality assurance, professional certification evaluation system, national quality standards, reform and innovation. In fact, we will meet difficulties. And we should make decision to face reality. Altogether, the ultimate aim is to improve promote the good development of higher education quality.
\end{abstract}

Keywords: Higher Education, Development, Quality, Assurance

\section{Introduction}

The Ministry of Education of People's Republic of China released the plan to expand the enrollment of higher vocational colleges by 1 million in China in june, 2009, which has become a "crucial step" for the popularization of higher education [1]. According to the Model Theory of massification of higher education by Martin Trow, the gross enrollment rate has exceeded $50 \%$, directly to the stage of popularization of higher education [2].

To some extent, the popularization of higher education has satisfied the aspiration of more people to go to college, but on the other hand, the expansion of quantity inevitably leads to problems related to quality. Quality is the eternal pursuit of higher education. Almost every country in the world attaches great importance to the improvement of higher education quality. Certainly, they pay attention to guaranteeing higher education quality by a series of measures [3].

Under the background of the popularization of higher education in China, it is very important to improve the quality and quantity of higher education.

\section{Histroy of Higher Education Quality Assurance in the World}

In the 1980s, developed countries took the lead in launching the quality assurance movement of higher education, with the quality problems brought by the rapid expansion of higher education. In the 1990s, many countries that experienced the popularization of higher education established the quality evaluation and guarantee system. Up to now, higher education quality assurance has been increasingly perfect in the developed countries. Such as, Higher Education Quality Certification Committee and Subordinate Six Regional Quality Certification Bodies in the United States, Commission for the Quality of Higher Education in France, Quality Assurance Agency for Higher Education in England, Higher Education Quality Assurance Agency in Australia [4]. In fact, a complete function of the quality assurance agency network 
has formed in the region, institutions and countries [5].

Higher education quality assurance started relatively late in China. It mainly charactered as the government-led and synchronized with the popular process of higher education [6]. At the end of the 20th century, Chinese government made a major decision to speed up higher education. In 1985, the Ministry of Education started the pilot work of evaluation of the level, specialty and curriculum of higher education, and ensured the quality of higher education by evaluation. It became the policy choice of the state and the direction of the reform of higher education management system in China. In August, 2004, the higher education teaching evaluation center formally was established, belonging to the Ministry of Education. This marked a critical step in establishing a higher education quality assurance system with Chinese characteristics [7].

With the further reform in China, colleges and universities have become independent legal entities and school-running subjects, so the government, society and universities have become three main bodies to monitor the quality of higher education [8]. In 2011, the national association of quality assurance and evaluation institutions of higher education was established. As a social organization, it is guided by the association of higher education, committed to the organizational construction and capacity improvement of national institutions of quality assurance and evaluation of higher education,. It actively played the role of social organizations in the public governance of education. So far, there have been 12 independent provincial educational evaluation institutions and over 300 school evaluation and construction institutions. Evaluation system in colleges and universities can improve campus construction. The construction of internal evaluation, as the main means of school education quality guarantee system, set up a variety of self-discipline and monitoring organization, such as academic committee, the committee, teaching teams, high school self quality control under the restriction of autonomy, pertinence [9]. They played an important role in quality assurance in the school.

\section{Development of Higher Education Quality Assurance in the World}

\subsection{Special Laws and Regulations for Quality Assurance}

More recently, all countries in the world have paid great attention and enthusiasm to the quality control guarantee of higher education.

Relevant laws and regulations were introduced. It basically formed a relatively complete system of quality supervision and control for the government, schools and the society. The UK has issued a new framework including education reform act and higher education since the 1980s. The Netherlands has promulgated the Open University law, the university education law (amendment) and the higher vocational education law [10].

National higher education bureau is responsible for the issued regulations in Sweden. It is respongsible for higher education quality control. In addition, the national evaluation board of France, the higher education inspection group of the Netherlands and the higher education accreditation board of the United States, they all play similar roles in high education quality management of higher education in these countries.

\subsection{Need for Cross-border Assessment}

In light of the expansion and diversification of the higher education system, more efforts have been made to develop transnational identification methods and quality assurance, and the search for consensus has gone a long way. Examples include peer review in Europe, university rankings, etc. The globalization of education and the broad demand for quality have led to the demand for cross-border assessment. The quality assessment of higher education has become one of the most prominent issues in the academic and higher education policy circles. In the 1980 s, the education system has been described as the "evaluation status" or part of the audit society. In terms of quality, the European association for quality assurance of higher education (ENQA) proposed common standards and quality assurance guidelines for European higher education areas in the Barcelona declaration. Among the different tools for evaluating the quality of higher education, the ranking is the most closely watched. In the international higher education, the European ranking, the United States certification system is highly valued [11]. Currently, the peer review system developed from the United States certification program is cited by almost all the certification programs in the world.

\subsection{Trend of Integration}

At present, there are two trends in the quality recognition and evaluation institutions of higher education in various countries in the world: one is the recognition and evaluation mode dominated by national government institutions, which tends to devolve power to local and non-governmental professional organizations; The other is the decentralized recognition evaluation mode dominated by local intermediary organizations, which tends to strengthen the central control. The general trend is the fusion of two kinds of patterns, for example, Australia is decentralization management education country [12]. Because of the fierce international competition and the continuous expansion of higher education, the government strengthen the control of university by the quality monitoring and funding mechanisms. All these aim to improve the quality of higher education and strengthen the vitality of higher education.

Social assessment organizations are active in the United States, They have developed from completely spontaneous behaviors to organized and systematic normative behaviors. Although the government does not directly interfere in the management of universities, it indirectly regulates the quality of universities through non-governmental quality assessment agencies and financial levers [13]. The government, society and universities have become the three main bodies to monitor 
the quality of higher education. The government carries out macro-control, while the non-governmental organizations set up different monitoring organizations to monitor the quality.

\section{Prospect for Higher Education Quality in China}

\subsection{Improve the Policy and Legal Basis for Quality Assurance}

The rule of law in education plays a leading, fundamental, normative and guaranteeing role in the process of education modernization. We should attach importance to the work of rule of law in education, make laws scientifically, strengthen law enforcement, and improve the quality of education by thinking and ways of rule of law. Legal basis of quality assurance policy need to be more perfect in China [14]. The degree regulations of the People's Republic of China promulgated in 1980. From then, China has already formed with eight department education law for more than 10 department of education administration regulations, more than 50 education department rules and a large number of local education regulations, rules. These cooperate each other with the education legal system of Chinese characteristics, but there is no special regulation in higher education quality assurance system.

In fact, there are only provisions on the evaluation of the quality of education and there are no provisions specifically explaining the content of quality assurance of higher education "education law" and "higher education law". of course, the ministry of education promulgated in the form of minister to the common colleges and universities teaching assessment ordinance in 1990. The ministry of education issued "interim measures for the articles of association of the institutions of higher learning set" in 2011. The ministry of education issued "regulations of ordinary higher school board (try out)"in 2014, which perfected the supervision mechanism including quality assurance aspects [15]. According to the demand of the Times, we should strive to establish and perfect the corresponding strategy of higher education quality at the national level and quality planning, quality requirements of the development of higher education.

Only when the laws are perfect, can the work be coordinated and developed. The establishment of laws and regulations on quality assurance can provide a direct basis and a good environment for quality assurance, so as to promote the process of quality assurance construction in China and promote the quality improvement of higher education.

\subsection{Establish a Good Professional Certification Evaluation System}

Professional certification can ensure the training quality of professional talents and reduce the influence of non-educational and academic factors on school running and discipline construction. It is the basic way of professional evaluation of higher education in developed countries.
The implementation of higher education certification in the United States is the core component of the quality assurance system. In China, to promote the establishment of professional certification bodies with independent legal personality, we should strengthen the contact and exchange with international higher education assessment and professional certification bodies [16]. With the internationally recognized professional certification system, the quality of professional training is guaranteed, and it also adapts to the international trend of cross-border evaluation.

By learning from the experience of international quality management certification in China, we promote professional certification, establish a new professional certification system, and strengthen the connection with international higher education evaluation and professional certification institutions, so we can connect with international standards, further implement and expand the autonomy of school running, deepen the reform of colleges and universities as soon as possible.

In 2011, the higher education teaching evaluation center of the Ministry of Education organized and implemented 180 pilot projects for undergraduate professional certification. In 2016, China formally joined the Washington agreement on international engineering education. As a full member of the Washington agreement, the certification results of China's engineering education quality have been recognized by 18 other member states (regions). It was reported by xinhuanet.com. that the higher education teaching evaluation center of the Ministry of Education and the China engineering education certification association had certified 846 engineering majors from 198 universities nationwide by 2017 [17]. We will encourage institutions of universities and vocational colleges to take an active part in the formulation of professional certification standards [18]. We speed up the establishment of a professional certification system with Chinese characteristics that is essentially equivalent to the international system.

\subsection{Formulate National Quality Standards for Higher Education}

Standard is the premise that ensures system construction. Only with standards can we strengthen guidance, oversight and accountability [19]. "Education Modernization 2035 in China" further proposes to improve the education quality standard system, and formulate education quality standards that cover the whole school sector, reflect the world's advanced level and meet the characteristics of different types of education at different levels. In 2018, the national standards for the class teaching of undergraduate course of common colleges and universities ", this is issued to the nation and the world's first national standards for higher education teaching, and the developing trend in the world attaches great importance to the talent training quality is consistent, the construction with Chinese characteristics, the level of higher education quality standards system has an important landmark significance. Under the framework of standards, specialized agencies and social intermediaries are encouraged to evaluate 
the level and quality of disciplines, specialties and courses of universities, so as to form an evaluation model for schools with Chinese characteristics and promote the establishment and improvement of quality assurance system.

\subsection{Deepen Reform and Innovation}

Higher education has entered the era of popularization in China. To adapt to the development of higher education globalization and internationalization, we should further deepen reform and innovation, and accelerate the construction and improvement of quality assurance, so we can effectively improve high education quality.

Innovation is the engine of development and reform is the booster. There is no end to social development and progress. Reform and innovation are always on the way. The state attaches great importance to higher education quality, which has been promoted for many times by the state. While drawing on the successful experience, the state has combined with the actual situation to constantly explore and innovate. The theoretical and practical level of higher education quality assurance has been constantly improved. With the popularization of higher education, On the way of reform and innovation, theory is the forerunner and improvement of practice level is the ultimate goal. We will further improve the quality assurance. Evaluation should be emphasized from the integration of compehensive evaluation, diversification of method and subject. We should encourage university teachers and education workers to explore to adapt to the pace of the new era from the content, form and method. We also reform and innovate, and put forward the new theory and method to do effect [20].

\section{Conclusion}

To strengthen the state, it is of great significance to develop higher education.

Now, China has entered the stage of the popularization of high education. Of course, we are also forced with chanllenges. We should have a clear aim to take active and vigorous measures to promote the quality assurance construction. The measures included policy, professional certification, standards and innovation. The ultimate goal is to improve the quality of education.

\section{References}

[1] Implementation plan for the special work of higher vocational college enrollment expansion, https://baike.sogou.com/v181436624.htm.

[2] Brubeck. Philosophy of higher education, 1987: 41.

[3] Terence w. biegolk, dean e. neubauer, Chief editor Yang guangfu; Ren youqun, chief translator, quality and public interest of higher education in the asia-pacific region, east China normal university press, 2012. 7.
[4] US. Department of Educaion, The Guide to Federal Suden Aid 2007-08.

[5] Sessing the Austrlin Inovation, The Welsh Joumal of Education 2002, 1 (1); 64-66.

[6] Dong xiaoping, su shanshan. China's higher education quality assurance culture: current situation, problems and countermeasures, Chongqing higher education research. 2017 (04).

[7] Yishan Yuan. research on teaching quality control and guarantee system of adult higher education, Research on continuing education. 2011 (03).

[8] Yukun Chen. Introduction to quality assurance system in higher education, 2004, Beijing normal university press.

[9] Yurong Zhou. introduction of six sigma management: transplanting innovation of quality management in colleges and universities, Contemporary education science. 2011 (03).

[10] Walk, David. Brtiish Goverment Plans to End Free Tution at Universties, The Chronicle of Higher Education. 1997, 43 (47): 35 .

[11] UNCTAD Informational Encounter on International Govermane Trade in Globalization for Economic Policy Research. 2003: 26-28.

[12] HongqinFang. Characteristics and enlightenment of internal teaching quality assurance system in British universities, Teaching in Chinese universities. 2013 (10).

[13] Donghua Lin. review and evaluation: development context, status analysis and future outlook -- based on the research of 51 participating universities, Science of modern education. 2016 (09).

[14] Liu qiang. on the reconstruction of the value concept and behavior model of the teaching quality assurance system in Chinese universities, Jiangsu higher education. 2018 (02).

[15] Yi Wei. Review and evaluation of undergraduate teaching, Hunan social sciences. 2017 (05).

[16] Qingzhong Chang. Four changes of audit and evaluation and internal quality assurance system construction in universities, teaching in Chinese universities. 2013 (07).

[17] Zhenchuan Zhang, Quanfeng, research on continuing education and its quality assurance from the perspective of TQM, Shi. Education and teaching forum. 2018 (33).

[18] Jianguo Xia, Chaohui zhao. Construction of "double closed-loop" teaching quality assurance system for newly-built undergraduate universities, Higher education in China. 2012 (08).

[19] Daobing Zhang. Research on service quality management of higher education based on six sigma theory, Theory and practice of contemporary education. 2016 (09).

[20] Yao rong. From policy thinking to rule of law thinking: the core of China's higher education governance modernization, Chongqing higher education research. 2019. (03). 